\title{
ADVANCES IN ANTIMITOTICS
}

\author{
Proceedings of the \\ First International Symposium \\ on Antimitotics \\ Rome, May I4-I6, Ig66
}

EDITED BY

L. Gedda, G. Cardinali, P. Parisi

AGTA GENETICAE MEDICAE ET GEMELLOLOGIAE 
Copyright (C) ${ }^{1967}$ by Acta Geneticae Medicae et Gemellologiae

TIPOGRAFIA POLIGLOTTA VATICANA 


\section{N D EXES}




\section{INDEX OF GONTENTS *}

Preface. . . . . . . . . . . . . . . . . VII

INDEX OF CONTRIBUTORS . . . . . . . . . . . . . . . . . XIII

L. Gedda (Rome) : Introduction to the Symposium . . . . . . . . . . . 3

F. S. Philips, H. S. Schwartz, S. S. Sternderg (New York) : Hydroxyurea: inhibition of DNA-synthesis and selective susceptibility of S-phase cells in vivo . . .

H. J. Seidel (Elberfeld): Experimental inhibition of the virus-induced Rauscher leukemia of the mouse . . . . . . . . . . . . . . 99 9

A. Fieschi, G. Sacchetti (Genova): Evaluation of the granulopoiesis during antiblastic treatment. . . . . . . . . . . . . . . 18

F. Gavosto, A. Pileri, L. Pegoraro (Torino): Proliferation kinetics of acute leukemia cells in relation to the chemotherapy . . . . . . . . . . $3^{\circ}$

E. H. Cooper, N. E. Topping (London): Effects of Melphalan on a sensitive and a resistant Yoshida ascites tumour................ 40

L. A. Elson (London): Growth inhibitory and haematological effects of alkylating agents and attempts at their modification to give greater selectivity of anti-tumour action

S. Garattini, M. G. Donelli, L. Morasca, C. Rainisio, R. Rosso (Milano): Attempts to establish new experimental methods to study antitumoral drugs . . .

A. De BardiERI (Milano): Synthesis and screening of substances acting by alkylation and metabolic inhibition ................. . . . . .

S. Eridani, R. Tiso, G. B. Ponti, R. Valentini (Milano): Biologic effects of recent antimitotic compounds . . . . . . . . . . . . 78

A. BASERGA (Ferrara): Cytologic dysplasia after treatment with antimitotic agents . . 99

A. Di Marco (Milano): Mechanism of action of Daunomycin . . . . . . . . . 102

R. Тном (Berlin): Fluorescence microscope and electron-microscope studies on the effect of Trenimon on human tumour cells . . . . . . . . . . . . . . I22

N. Quattrin, E. Dini, R. Montuori (Napoli): Trenimon treatment in chronic hemoblastoses

* Italiano: pag. 305; Français: p. 307; Deutsch: S. 309. 
G. Brulé, S. Hane (Villejuif): Our experience with 5-Fluoro-2- Desoxyuridine . . . I53

W. Bollag (Basel): Experimental studies with Methylhydrazine derivatives . . . . I58

P. Introzzi, G. Marinone (Pavia): Role of Methylhydrazine in the treatment of Hodgkin's disease . . . . . . . . . . . . . . . . . . . . . . . . . . . I I I

N. Quattrin, R. Montuori (Napoli): Treatment of some chronic hemoblastoses with a derivative of Methylhydrazine (Natulan). . . . . . . . . . I 78

G. Astaldi (Tortona): Introduction to the general discussion on the cytological and haematological effects of antimitotics . . . . . . . . . . . . . . . . . . I80

P. Dustin (Bruxelles): Some observations on the cytological effects of antimitotic poisons . . . . . . . . . . . . . . . . . . . . . . . 182

L. Gedda, G. Gardinali (Roma): The stathmokinetic agents . . . . . . . . . . 185

J. G. Armstrong (Indianapolis): New derivatives of the Vinca rosea alkaloids . . . 193

G. Cardinali, G. Gardinali, G. Genturelli (Roma): The Catharanthus iroseus (Vinca rosea) "alkaloids: a new class of stathmokinetic agents . . . . . . .

A. Colarizi, G. Stegagno, G. Digilio, G. Multari (Roma): Vincristine sulphate in the treatment of acute leukemia of childhood . . . . . . . . . . . . . .

E. Storti, A. Traldi, D. Quaglino (Modena): Clinical studies on the effect of Imuran and Vincristine in the treatment of leukaemia . . . . . . . . . . . . . .

E. Anglesio, A. Galciati, V. Caramello (Torino): The treatment of lymphomas with Vincaleukoblastine and Methylhydrazine . . . . . . . . . . . . . . 232

G. Mathé, M. Sahneider, L. Schwarzenberg, A. Cattan, J. L. Amiel, J. R. Schlumberger (Villejuif): Personal experience on the chemiotherapy of leukemias et hematosarcomas . . . . . . . . . . . . . . . . . . . . .

N. QuatTrin, E. Dini (Napoli): Use of new chemotherapeutic agents in acute and chronic myeloid leukemia........................

D. Taglioretti, A. Giangrande (Milano): Azathioprine in myeloproliferative and autoimmune disorders.

J. G. Armstrong (Indianapolis): Current problems in the use of the oncolytic drugs

A. Baserga (Ferrara): The different interpretations of the mechanism of action of antimitotics and the actual treatment of malignant hemopathies . . . . . .

H. Gerhartz, K. E. Hampel (Berlin): The selectivity of effectiveness of cytostatic agents. . . . . . . . . . . . . . . . . . . . . . . . 283

G. Stecher, G. Reinhardt (Freiburg): Ghemotherapy in polycythemia vera . . . 292

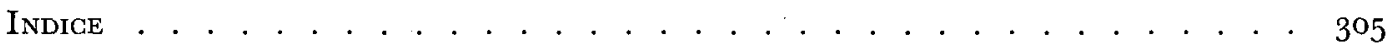

Table des Matières . . . . . . . . . . . . . . . . . . . . . . 307

INHALT . . . . . . . . . . . . . . . . . . . . . . . . . 309 